\title{
Review \\ FKBP52 in Neuronal Signaling and Neurodegenerative Diseases: A Microtubule Story
}

\author{
Béatrice Chambraud $^{1}$, Cillian Byrne ${ }^{2,3}$, Geri Meduri ${ }^{2}$, Etienne Emile Baulieu ${ }^{1,2, * \mathbb{D}}$ and Julien Giustiniani ${ }^{1,2, * \mathbb{D}}$ \\ 1 INSERM U1195, Université Paris-Saclay, 80 Rue du Général Leclerc, 94276 Kremlin-Bicêtre, France; \\ beatrice.chambraud@inserm.fr \\ 2 Institut Professeur Baulieu, 80 Rue du Général Leclerc, 94276 Kremlin-Bicêtre, France; \\ cillian.byrne@sorbonne-universite.fr (C.B.); geri.meduri@inserm.fr (G.M.) \\ 3 Laboratoire des Biomolécules, LBM7203, CNRS, École Normale Supérieure, PSL University, \\ Sorbonne Université, 75005 Paris, France \\ * Correspondence: etienne.baulieu@inserm.fr (E.E.B.); julien.giustiniani@inserm.fr (J.G.); \\ Tel.: +33-1-49-59-18-72 (J.G.); Fax: +33-1-49-59-92-03 (J.G.)
}

\begin{abstract}
The FK506-binding protein 52 (FKBP52) belongs to a large family of ubiquitously expressed and highly conserved proteins (FKBPs) that share an FKBP domain and possess Peptidyl-Prolyl Isomerase (PPIase) activity. PPIase activity catalyzes the isomerization of Peptidyl-Prolyl bonds and therefore influences target protein folding and function. FKBP52 is particularly abundant in the nervous system and is partially associated with the microtubule network in different cell types suggesting its implication in microtubule function. Various studies have focused on FKBP52, highlighting its importance in several neuronal microtubule-dependent signaling pathways and its possible implication in neurodegenerative diseases such as tauopathies (i.e., Alzheimer disease) and alpha-synucleinopathies (i.e., Parkinson disease). This review summarizes our current understanding of FKBP52 actions in the microtubule environment, its implication in neuronal signaling and function, its interactions with other members of the FKBPs family and its involvement in neurodegenerative disease.
\end{abstract}

Meduri, G.; Baulieu, E.E.; Giustiniani, J. FKBP52 in Neuronal Signaling and Neurodegenerative Diseases: A

Microtubule Story. Int. J. Mol. Sci. 2022, 23, 1738. https://doi.org/ $10.3390 /$ ijms 23031738

Academic Editors: Lucio Tremolizzo and Gessica Sala

Received: 20 December 2021

Accepted: 28 January 2022

Published: 3 February 2022

Publisher's Note: MDPI stays neutral with regard to jurisdictional claims in published maps and institutional affiliations.

Copyright: (c) 2022 by the authors. Licensee MDPI, Basel, Switzerland. This article is an open access article distributed under the terms and conditions of the Creative Commons Attribution (CC BY) license (https:// creativecommons.org/licenses/by/ $4.0 /)$.

\section{Introduction}

FK506-binding proteins (FKBPs) belong to a subclass of the highly conserved immunophilin family which comprises a number of multifunctional proteins originally defined by their capacity to bind the immunomodulator FK506. FK506 binding domains harbor a Peptidyl-Prolyl cis/trans Isomerase (PPIase) activity that catalyzes the conversion of Peptidyl-Prolyl bonds between cis and trans conformations, resulting in a rate limiting change of protein conformation and function [1,2]. PPIase activity is known to be inhibited by immuno-suppressant molecules such as FK506 and Rapamycin via a gain of function mechanism mediating immune suppression [3-5]. This activity provides new perspectives to elaborate original therapeutic strategies targeting FKBPs and their ligands. First identified in human T lymphocytes, immunophilins have a wide distribution and are particularly abundant in the nervous system, suggesting unexpected and novel functions distinct from immuno-modulatory effects. Indeed, neuroprotective effects of FK506 have been reported [6,7]. In the past decade, several studies have highlighted neuronal functions of FKBPs and identified various signaling pathways in which FKBP52, a large molecular weight member of FKBPs, plays an active role. Moreover, FKBPs and in particular FKBP52, have been associated with a number of pathologies including hormone-dependent and stress related diseases [8,9], cancer [10,11] and neurodegenerative diseases [12-14]. In this review, we provide an overview of FKBP52 action in regulating different signaling pathways in the microtubule (MT) environment, its interchange with other members of the FKBP family, its neurological functions and involvement in neurodegenerative diseases. 


\section{FKBP52, a Member of FKBP Family Proteins}

Several FKBPs have been detected in mammals and named according to their molecular mass (e.g. the $12 \mathrm{kDa}$ FKBP12). The smallest FKBPs, such as FKBP12, which is the first discovered and much investigated prototypic member of the immunophilin family $[5,15]$, are composed almost entirely of a PPIase motif in a single domain whereas the larger FKBPs are composed of functionally independent domains. All of these FKBPs show a wide distribution and are particularly abundant in the nervous system $[6,16]$. FKBPs are historically classed into three categories depending of their subcellular localization: Cytoplasmic, Nuclear and Endoplasmic Reticulum (ER). FKBP12 and FKBP12.6 are mostly diffuse throughout the cytoplasm [5,7] whereas larger FKBPs are localized in the ER [17-23], in the nucleus [24-27], in different organelles [28,29] or are associated with the cytoskeleton [30-32] suggesting different functions for these FKBPs (Table 1, [33-50]). 
Table 1. List of human FKBPs: cellular location, function and central nervous system (CNS) disease association.

\begin{tabular}{|c|c|c|c|c|c|c|}
\hline Gene & FKBPs & $\begin{array}{c}\text { FK506 } \\
\text { Binding/PPIase } \\
\text { Activity }\end{array}$ & Cellular Location & Cellular Function & CNS Expression & CNS Disease Association \\
\hline$F K B P 1 a$ & FKBP12 & Yes/Yes & Cytoplasm & $\begin{array}{c}\text { - Regulates Tau aggregation [33] } \\
\text { - Regulates APP processing [34] } \\
\text { - Increases } \alpha \text {-Syn aggregation [13,51,52] } \\
\text { - Regulates ryanodine receptors (RyRs) [35] }\end{array}$ & $\begin{array}{l}\text {-Detected in all brain regions and } \\
\text { spinal cord } \\
\text {-Expressed in Neurons and } \\
\text { dystrophic neurites [53] }\end{array}$ & $\begin{array}{c}\text { - Tauopathies (AD) } \\
\text { - } \alpha \text {-Synucleinopathies (PD) }\end{array}$ \\
\hline$F K B P 1 b$ & FKBP12.6 & Yes/Yes & Cytoplasm & - Regulates ryanodine receptors (RyRs) [35] & $\begin{array}{c}\text { Detected in all brain regions and } \\
\text { spinal cord }\end{array}$ & $\mathrm{AD}[35]$ \\
\hline FKBP2 & FKBP13 & Yes/Yes & $\begin{array}{l}\text { Endoplasmic } \\
\text { reticulum }\end{array}$ & -ER Chaperone [20] & $\begin{array}{c}\text { Detected in all brain regions and } \\
\text { spinal cord }\end{array}$ & Unknown \\
\hline FКBР3 & FKBP25 & Yes/Yes & $\begin{array}{l}\text { Nucleus and } \\
\text { cytoplasm }\end{array}$ & $\begin{array}{c}\text { - Regulates MT dynamics and is involved in } \\
\text { Nucleus-Cytoplasm shuttling [32] } \\
\text { - Regulates p53 signaling [36] }\end{array}$ & $\begin{array}{l}\text { - Detected in all brain regions and } \\
\text { spinal cord } \\
\text {-Expressed in neurons }\end{array}$ & Unknown \\
\hline FKBP4 & FKBP52 & Yes/Yes & $\begin{array}{l}\text { Cytoplasm, nucleus, } \\
\text { MT network, } \\
\text { endo-lysosomal } \\
\text { system }\end{array}$ & $\begin{array}{c}\text { - Regulates Tau aggregation [54-56] } \\
\text { - Increases } \alpha \text {-Syn aggregation }[13,52] \\
\text { - Regulates MT dynamics [12,31] } \\
\text { - Regulates MT-dependent trafficking (i.e., SHR, } \\
\text { Nf-kappaB, IRF4, hTERT) [57-60] } \\
\text { - Involved in ALP function [61] }\end{array}$ & $\begin{array}{l}\text { - Detected in all brain regions and } \\
\text { spinal cord } \\
\text { - Highly expressed in neurons }\end{array}$ & $\begin{array}{c}\text { - Tauopathies (AD) } \\
\text { - } \alpha \text {-Synucleinopathies (PD) }\end{array}$ \\
\hline FKBP5 & FKBP51 & Yes/Yes & $\begin{array}{l}\text { Cytoplasm, nucleus, } \\
\text { MT network, } \\
\text { mitochondria }\end{array}$ & $\begin{array}{c}\text { - Regulates Tau aggregation [62] } \\
\text { - Regulates MT dynamics [63] } \\
\text { - Regulates MT-dependent trafficking (i.e., SHR, } \\
\text { Nf-kappaB, hTERT) }[57,59,64] \\
\text { - Involved in ALP function [65] }\end{array}$ & $\begin{array}{l}\text { - Detected in all brain regions and } \\
\text { spinal cord } \\
\text { - Highly expressed in neurons }\end{array}$ & $\begin{array}{c}\text { - Tauopathies (AD) } \\
\text { - } \alpha \text {-Synucleinopathies (PD) } \\
\text { - Huntington disease [37] } \\
\text { - Stress-related and } \\
\text { psychiatric diseases [8] }\end{array}$ \\
\hline FKBP6 & FKBP36 & No/Yes & $\begin{array}{l}\text { Cytoplasm and } \\
\text { nucleus }\end{array}$ & $\begin{array}{l}\text { - Regulates GAPDH signalling [46] } \\
\text { - Involved in spermatogenesis [38] }\end{array}$ & Undefined & - Williams-Beuren syndrome [39] \\
\hline FKBP7 & FKBP23 & Undefined/Yes & $\begin{array}{l}\text { Endoplasmic } \\
\text { reticulum }\end{array}$ & $\begin{array}{l}\text { - Calcium binding ability [23] } \\
\text { - Regulates interaction with BiP [40] }\end{array}$ & $\begin{array}{l}\text { - Detected in all brain regions and } \\
\text { spinal cord }\end{array}$ & Unknown \\
\hline FKBP8 & FKBP38 & No/Yes & Mitochondria & $\begin{array}{l}\text { - Involved in mitophagy [66] } \\
\text { - Inhibits apoptosis [47] } \\
\text { - Endogenous inhibitor of mTOR [41] }\end{array}$ & $\begin{array}{l}\text { - Detected in all brain regions and } \\
\text { spinal cord } \\
\text {-Expressed in neurons }\end{array}$ & Unknown \\
\hline
\end{tabular}


Table 1. Cont.

\begin{tabular}{|c|c|c|c|c|c|c|}
\hline Gene & FKBPs & $\begin{array}{c}\text { FK506 } \\
\text { Binding/PPIase } \\
\text { Activity } \\
\end{array}$ & Cellular Location & Cellular Function & CNS Expression & CNS Disease Association \\
\hline FKBP9 & FKBP60 & Yes/Yes & $\begin{array}{l}\text { Endoplasmic } \\
\text { reticulum }\end{array}$ & -Possible role in prion propagation or clearance [42] & $\begin{array}{l}\text { Detected in all brain regions and } \\
\text { spinal cord }\end{array}$ & Unknown \\
\hline FKBP10 & FKBP65 & Yes/Yes & $\begin{array}{l}\text { Endoplasmic } \\
\text { reticulum }\end{array}$ & $\begin{array}{l}\text { - Possible neuroprotective effect linked to } \\
\text { regulation of protein folding [43] } \\
\text { - Participates in type I procollagen folding [44] }\end{array}$ & $\begin{array}{l}\text { Detected in all brain regions and } \\
\text { spinal cord }\end{array}$ & Unknown \\
\hline FKBP14 & FKBP22 & Yes/Yes & $\begin{array}{l}\text { Cytoplasm, } \\
\text { Endoplasmic } \\
\text { reticulum }\end{array}$ & $\begin{array}{l}\text { - Involved in protein folding, trafficking and in } \\
\text { collagen synthesis [22] } \\
\text { - Regulates Presenilin and Notch signalling [45] }\end{array}$ & $\begin{array}{l}\text { Detected in all brain regions and } \\
\text { spinal cord }\end{array}$ & Unknown \\
\hline FKBP15 & FKBP133 & No/No & $\begin{array}{l}\text { Cytoplasm, nucleus } \\
\text { and endosome }\end{array}$ & $\begin{array}{l}\text { - Possible role in cytoskeletal organization of } \\
\text { neuronal growth cones [67] } \\
\text { - Involved in early endosomes transport [67] }\end{array}$ & $\begin{array}{l}\text { Detected in all brain regions and } \\
\text { spinal cord }\end{array}$ & Unknown \\
\hline$F K B P L$ & FKBP-L & No/No & Cytoplasm & - Regulates MT-dependent trafficking of GR [50] & $\begin{array}{l}\text { Detected in all brain regions and } \\
\text { spinal cord }\end{array}$ & Unknown \\
\hline
\end{tabular}


FKBP52, one of the larger FKBPs localized both in the nucleus and the cytoplasm, is composed of four functional domains ([68]; Figure 1): two consecutive FK506-binding domains namely FK1 (residues 31-139) and FK2 (residues 149-267), a TetratricoPeptide Repeat (TPR) domain and an $\alpha$-helix in its extreme C-terminus that contains a putative calmodulin binding site [69]. FK1 is the only binding site for FK506 and presents peptidylprolyl isomerase (PPIase) activity, while the FK2 domain, which shares $34 \%$ identity with FK1, does not bind FK506, is probably more correctly defined as an FKBP-like domain and harbors an ATP (GTP) binding site [3,70]. Another noteworthy structural aspect of the FKBP52 is the presence in the third domain of a TPR with a chaperone activity [71] which is also a binding site for the molecular heat shock protein chaperone of $90 \mathrm{kDa}(\mathrm{Hsp} 90)$ [72].
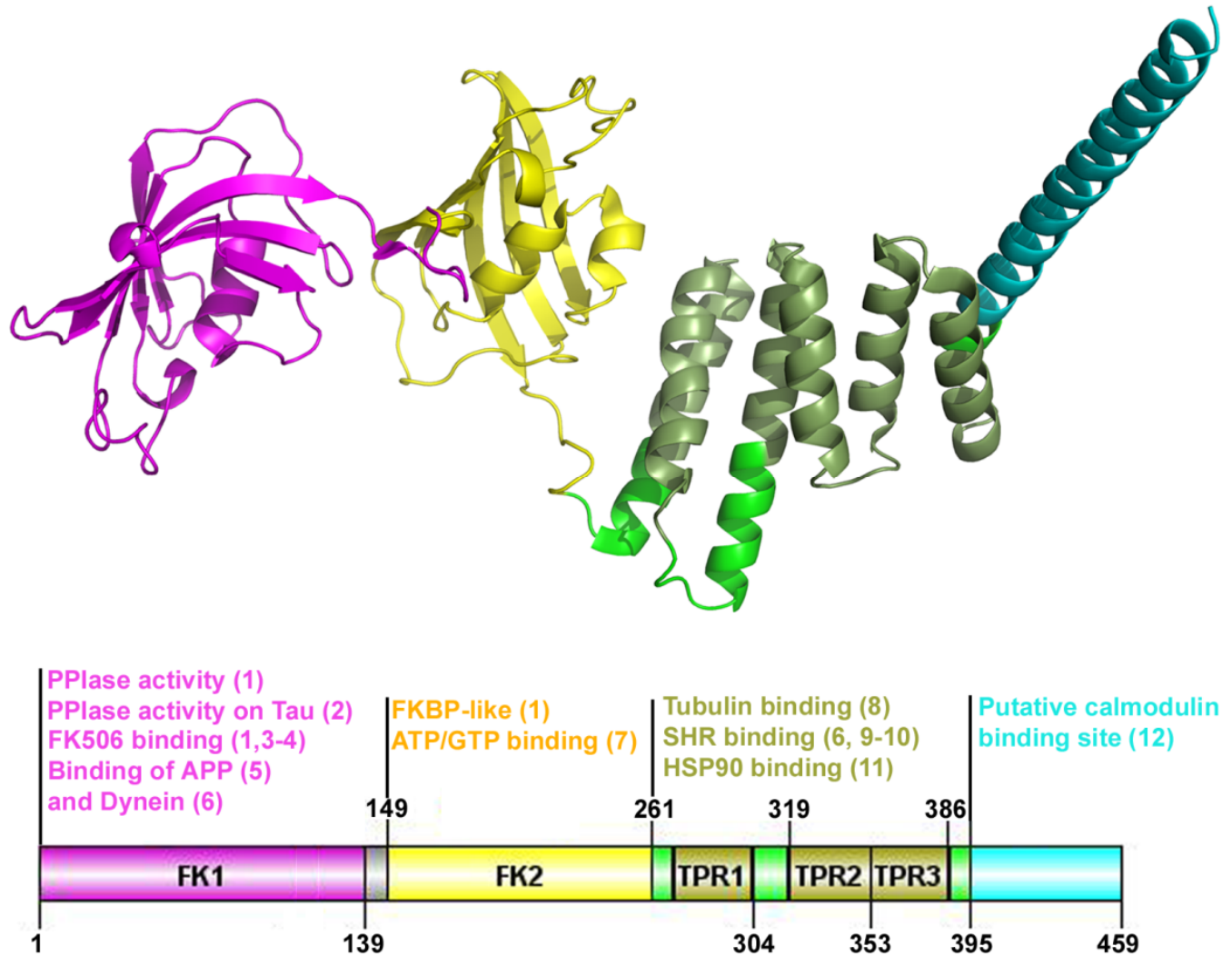

Figure 1. The three-dimensional structure of FKBP52 (aa1_459) showing the main structural domains. Functional domains are colored. The cartoon is generated with Pymol v0.99 and DOG 2.0. APP: amyloid precursor protein; FK: FK506 binding domain; Hsp90: heat shock protein of $90 \mathrm{kDa}$; SHR: steroid hormone receptor; TPR: tetratricopeptide repeat. References: (1) Chambraud et al, 1993; (2) Kamah et al, 2016; (3) Schreiber et al, 1991; (4) Harding et al, 1989; (5) Sanokawa-Akakura et al, 2010; (6) Silverstein et al, 1999; (7) Le Bihan et al, 1993; (8) Chambraud et al, 2007; (9) Tai et al, 1986; (10) Renoir et al, 1990; (11) Radanyi et al, 1994; (12) Massol et al, 1992.

FKBP52 is partially associated with the MT network in different cell types suggesting an implication in MT function [30]. MTs are key cytoskeletal components that play an important role in neuronal architecture, intracellular trafficking and signaling [73,74].They are highly regulated and possess a dynamic character allowing them to continuously migrate through the cytoplasm. Originally discovered in association with steroid hormone receptors (SHR), FKBP52 is involved in endocrine signaling in a MT-dependent manner [75-77]. This is also the case for FKBP51, a close-related partner of FKBP52, with whom it shares $75 \%$ similarity and $60 \%$ identity $[8,68,78]$. In spite of their high homology, these FKBPs show different conformational dynamics [79] and both immunophilins usually compete for binding to target proteins, have competing functional properties and elicit different biologi- 
cal effects $[57,80]$. However, some exceptions have been described showing a redundancy of some effects of these FKBPs $[58,64]$.

\section{FKBP52 in Microtubule Dynamics}

In accordance with previous reports about the localization of FKBP52 in association with the microtubular network in mouse neuronal cells [30], our group has shown that FKBP52 is able to interact with the neuronal tubulin preventing in vitro MT formation [31]. The inhibition of MT polymerization involves the C-terminal region of FKBP52 and is independent of its PPIase activity. Consistent with these observations, FKBP12 has no effect on tubulin polymerization in vitro. Likewise, depletion of FKBP52 stimulates neurite extension in an undifferentiated PC12 rat pheochromocytoma cell line suggesting that FKBP52 could contribute to neurotrophic effects via its regulation of MT dynamics [31]. Conversely, certain results showed that neurite outgrowth in vitro in embryonic hippocampal cells was favored by FKBP52 overexpression [81]. This discrepancy might be explained by a possible cell type-dependent role of FKBP52. FKBP52 was also found to associate with canonical transient receptor potential channels TRPC1 and to control chemotropic guidance of neuronal growth cones, which implicates the rearrangement of the cytoskeleton, via the regulation of TRPC1 channel opening [82]. As TRPC1 was shown to inhibit $\mathrm{Ca}^{2+}$ influx and as calcium plays an important role in MT depolymerization [83], FKBP52 might indirectly modulate MT dynamics locally in the growth cones. In the same vein, FKBP52 was found to interact with TRPC3 [84] and TRPV5 [85] in different epithelial cells, and to inhibit $\mathrm{Ca}^{2+}$ influx but their neuronal involvement still remains to be analyzed. Moreover, we have found that FKBP52 interacts with Tau (Tubulin associated unit), a neuronal protein implicated in tubulin polymerization, and have demonstrated an antagonist effect of FKBP52 on Tau promoted tubulin assembly [12]. In contrast to the effect of FKBP52, it has been shown that FKBP51 promotes MT stabilization via its interaction with Tau and Hsp90 [63]. Altogether, these observations suggest an antagonistic action of these two FKBPs on the regulation of Tau-dependent MT dynamics in neurons. FKBP25 is also able to promote tubulin polymerization and stabilize the MT network in various cell lines but its involvement in neurons still remains to be investigated [32]. Moreover, another large FKBP, called FKBP133, has been localized in the neuronal microtubular network and has been suggested to play a role in membrane trafficking and axonal outgrowth $[27,67]$. Additional studies need to be done to evaluate the involvement of FKBP25 and FKBP133, and also of the other FKBPs previously listed in Table 1, in MT formation and particularly in Tau-induced tubulin polymerization. All these findings taken together indicate the implication of some FKBPs including FKBP52 in MT dynamics and their place in the large family of cytoskeleton-modulating proteins.

\section{FKBP52 in Microtubule-Dependent Trafficking}

In addition to its implication in MT dynamics, FKBP52 has been shown to play important roles in protein trafficking along the MT network, regulating various physiological processes to maintain brain homeostasis. For example, it has been observed in different cell lines including neurons that FKBP52, in close interaction with Hsp90 and the dynein/dynactin complex, is implicated in the retrograde transport and translocation of different steroid receptors such as the glucocorticoid receptor (GR) [57,77,80,86,87]. Glucocorticoids act as peripheral effectors of the hypothalamic-pituitary-adrenal (HPA) axis and interact with the GR modulating response to stress and inflammation, synaptic physiology and circuitry, and also behavior [88]. While the TPR domain of FKBP52 binds to the C-terminal EEVD peptide motif in Hsp90 [89,90], the PPIase domain interacts with the dynein complex [86]. This complex binds with high affinity the hormone bound activated GR inducing its nuclear translocation and mediating its transcriptional response [91]. In contrast, FKBP51 does not interact with dynein and, through competition with FKBP52, is able to disrupt the GR-dynein association thereby impairing nuclear translocation [80]. The latter study describes an antagonistic action of FKBP52 and FKBP51 in the regula- 
tion of GR signaling as observed in neuronal MTs dynamics. It has also been shown that FKBP12 does not compete with FKBP52 for dynein binding suggesting that FKBP12 is not involved in GR translocation [86]. Similarly to FKBP52, FKBP-L is an additional player in the Hsp90/Dynein/GR complex leading to GR nuclear translocation and transcriptional activity [50].

It was also shown that both FKBP52 and FKBP51 modulate the nuclear translocation of the p50.RelA/p65 complex and affect the transcriptional activity of Nuclear Factor K-light chain enhancer of activated lymphocyte B cells (Nf-kappaB) which plays a key role in inflammation and immune function [59,92-94]. Nf-kappaB is translocated to the nucleus by a MT-dependent mechanism in hippocampal neurons analogously to the nuclear shuttling occurring during steroid hormone signaling to regulate expression of several genes involved in neuroplasticity and cell survival [95]. In T and B lymphocytes, FKBP52 inhibits IRF-4 (interferon regulatory factor 4) transactivation via its PPIase activity and possibly acts as a chaperone to escort IRF-4 into the nucleus by the same MT-dependent transport. However, the latter action still remains to be investigated [60]. In neurons, IRF4 is a neuroprotective factor from ischaemia/reperfusion-induced degeneration and apoptosis both in vivo and in vitro [96]. It has also been shown in rat dorsal root ganglion neurons that FKBP52 interacts with Atox1 (Antioxidant Protein 1), a copper-binding metallochaperone, and is involved in copper transport [97]. This transport might also be mediated through the same FKBP/Dynein complex along a MT lattice [98] and possibly plays a role in inflammation processes [99]. These observations indicate that large FKBPs including FKBP52 are involved in neuroplasticity, inflammation and cell survival, possibly through regulation of MT protein trafficking as shown for GR and Nf-KappaB signaling.

The same FKBP52/Dynein complex is involved in the retrograde transport of both the tumor suppressor p53 [100,101] and the human telomerase reverse transcriptase hTERT [58] along the MT network promoting their nuclear translocation and transcriptional activity; however, their possible involvement in neuronal functions still remains to be elucidated. Recently, we have shown that FKBP52 is located in the endo-lysosomal system of different neuronal cells and that FKBP52 deficiency impacts the lysosomal positioning during a proteotoxic stress $[29,61]$. Knowing that lysosomal movement toward the nucleus is MTdependent and mediated by dynein motors [102], we hypothesized that the role of FKBP52 in protein trafficking might be also extended to the retrograde lysosomal transport [61]. In the same way, FKBP133 depletion results in altered endosomal transport towards the lysosomes suggesting an implication of FKBPs in membrane trafficking [67]. FKBPs and particularly FKBP52 are thus involved in protein and membrane trafficking along the MT network which regulates MT-dependent signaling dynamics in the cytoplasm.

\section{FKBP52 in Microtubule-Associated Protein Aggregation and Clearance}

MT stability and function are highly regulated by different MT-associated proteins including some neuronal aggregation-prone proteins such as Tau and alpha-synuclein ( $\alpha$-syn). Both proteins have been shown to polymerize MTs in vitro [103-106] and to be involved in MT-dependent trafficking $[107,108]$. Both proteins can also aggregate and generate toxic intracellular deposits that induce MT alterations and neuronal death $[109,110]$. Whereas protein aggregation is closely associated with neuronal toxicity, it has been suggested that protein aggregates could also represent a neuronal protective response during stress depending on the nature, the size and also the neuronal load levels of these aggregates [111-113].

In addition to its regulation of Tau-induced tubulin polymerization, we have recently demonstrated that FKBP52 is also able to modulate Tau aggregation in vitro [54,55]. These studies show that FKBP52 has no effects on full-length Tau aggregation (HT40 isoform), whereas we demonstrate a distinct FKBP52 activity upon truncated and mutated Tau forms independent of its PPIase activity [56]. Similarly, it has been shown that FKBP52 is also able to accelerate $\alpha$-syn aggregation $[13,51,52]$. Other FKBPs can also affect the oligomerization 
and aggregation of Tau and $\alpha$-syn but the physiological role of this particular action still remains elusive $[33,62,114]$ (see Table 1 ).

FKBP52 and FKBP51 are known to interact with Hsp90 acting as co-chaperones to maintain protein quality control during stress [9]. It has been reported that Hsp90 regulates Tau function $[115,116]$ and synergizes with FKBP51 to block Tau degradation resulting in Tau oligomerization under pathological conditions $[63,114]$. Whereas some chaperones/cochaperones stimulate Tau aggregation in vitro, others are thought to inhibit or reverse this process suggesting that this chaperone machinery might regulate the levels of Tau aggregation [117-119]. Different chaperones have also been found to modulate $\alpha$-syn aggregation without evidence of synergy with FKBPs in this aggregation process [120,121].

Both Tau and $\alpha$-syn aggregates are known to be degraded through the autophagylysosomal pathway (ALP) [122,123]. ALP is a MT-dependent degradation pathway involved in the clearance of abnormal protein aggregates in order to maintain protein homeostasis and neuronal health [124]. Indeed, MTs are involved in different steps of autophagy including motility of autophagosomes and lysosomes using MT-interacting molecular motors such as dynein and kinesins $[125,126]$. One possible explanation of FKBP implication in the control of protein aggregation might be found in their involvement in neutralizing soluble and toxic oligomeric forms of Tau, and/or $\alpha$-syn, inducing their degradation and clearance under stress conditions. Our recent observations showed a localization of FKBP52 in the lysosomes of healthy human brain neurons [29,61]. In the latter study, we showed that FKBP52 modulates ALP function during Tau-induced proteotoxic stress by modulating perinuclear lysosomal positioning and clustering, an important lysosomal process involved in protein degradation during stress [61]. Interestingly, recent studies have also reported the involvement of other FKBPs in ALP function $[65,66]$. These results might suggest a synergistic role of FKBP52 in the MT environment (1) through regulation of MT-dependent aggregation of proteins such as Tau and $\alpha$-syn in association with other chaperones and/or FKBPs and (2) through contributing to the efficient degradation and clearance of these protein aggregates via the ALP during stress.

\section{Involvement of FKBP52 in Neurodegenerative Diseases}

Abnormalities in neuronal MT functions such as network stability and defective transport along the axon lead to brain diseases [127]. Indeed, alterations and aggregation of Tau and $\alpha$-syn, which both impact MT assembly and signaling, are critical for the development of major neurodegenerative diseases called tauopathies including Alzheimer disease (AD) and synucleinopathies such as Parkinson disease (PD) respectively [128-130]. In these pathologies, the loss of MT function is accompanied by a gain of toxicity of Tau or $\alpha$-syn both leading to neuronal death [131-135]. The pathogenesis of AD is also believed to be linked to an abnormal production of the $\beta$-amyloid peptide $(\mathrm{A} \beta)$ produced through the proteolytic processing of a transmembrane protein called amyloid precursor protein (APP) and which accumulates extracellularly, forming amyloid plaques $[136,137]$. It has been shown that $A \beta$ peptides cause rapid MT loss in a Tau-dependent manner in cultured neurons linking $A \beta$ and Tau to the detrimental neurodegeneration observed in $A D$ [138]. Given the important role of FKBP52 and other FKBPs in the MT environment, a different modulation of their expression and/or a deviance of their function under pathological conditions are thought to contribute to the alterations of MT-dependent signaling dynamics thus impacting neuronal function and health. FKBP52 protein expression is strongly decreased in the frontal cortex of AD and FTLD-Tau brains (Frontotemporal Lobar Degeneration linked to a point-mutation of the Tau gene (i.e Tau-P301L)) [139] whereas no indication has been provided to date concerning the expression of FKBP52 in affected brain regions of PD patients. It has also been reported that the expression of other FKBPs is altered in these pathologies. For example and in contrast to FKBP52, FKBP51 is increased in different brain regions of patients with $\mathrm{AD}$ including the frontal and temporal cortex [114]. The latest observation is consistent with the recent study showing the ability of FKBP51 to modulate the expression of FKBP52 in the mouse brain and speculating for an inverse correlation 
between FKBP51 and FKBP52 expression levels in human brain [140]. FKBP12 immunoreactivity is also increased in the hippocampus and the frontal cortex of patients with $\mathrm{AD}$ and PD [16] whereas its expression is decreased in angular cortices of AD brains [53].

\subsection{FKBP52 and Microtubule Dynamics}

The P301L mutation of the Tau gene, which has been observed in patients with FTLDTau [141], results in a reduced ability of Tau to promote MT assembly. This mutation is linked to abnormal axonal outgrowth and branching in defective spinal primary motoneurons in the hTau-P301L zebrafish model [142,143]. Our team has shown that the FKBP52 interaction with Tau (both wild-type and TauP301L) has a considerable impact on the progression of the early manifestations of the tauopathy in vivo, because in the model of hTau-P301L zebrafish mutant used for the study, the early axonal growth defects are rescued by FKBP52 knock down [54]. Given that FKBP52 is able to prevent Tau-induced tubulin polymerization and MT formation [12,31], reducing its interaction with wild-type Tau probably improves the defective MT dynamics and stability engendered by the mutated Tau. However, reducing the levels of FKBP52 does not decrease neuronal toxicity in the spinal cord of hTau-P301L zebrafish larvae, but rather tends to increase neuronal cell death in this pathological context. These results underline the importance of maintaining normal FKBP52 expression levels on neuronal survival and suggest a double-edged sword function of FKBP52 in this neurodegenerative model [54].

\subsection{FKBP52 in Protein Aggregation and Clearance}

FKBP52 decrease in AD brains is correlated with the accumulation and aggregation of pathological Tau [29]. In our previous studies, we proposed that FKBP52 might play a role in Tau degradation [12,139], and we showed that FKBP52 is present in the endolysosomal system of human brain neurons [61]. As previously discussed, FKBP52 is able to promote in vitro oligomerization of different truncated or mutated Tau species $[54,55]$ and to accelerate $\alpha$-syn aggregation [13,51,52]. In the case of Tau proteins, it has been shown that amyloidogenic Tau fragments, expressed in a mouse neuroblastoma cell line, are targeted to the lysosome surface where they aggregate to be eventually degraded through the ALP [122]. Thus, we propose that FKBP52 might participate to the aggregation of Tau at the surface of the lysosome, leading to Tau degradation through the ALP. This particular FKBP52 action might possibly expand to other aggregation-prone proteins such as $\alpha$-syn. If we consider that FKBP52 modulates Tau aggregation synergistically with other FKBPs/chaperones in the lysosomal environment in order to degrade these aggregates, we might also suppose that its decreased expression in AD brain neurons could disturb this highly regulated process. Tau oligomers/small aggregates would escape in the cytoplasm during their lysosomal degradation thus progressively propagating abnormal and uncontrolled Tau aggregation in a prion-like manner as described [144-146]. Moreover, the recent observations showing an involvement of FKBPs in ALP function highlight a possible synergistic role of these FKBPs in Tau aggregation and clearance [61,65]. Indeed, we recently demonstrated that FKBP52 deficiency impairs autophagy facilitating Tau accumulation during Tau-induced proteotoxic stress in a human neuronal cell line and in TauP301S dorsal root ganglion neurons, suggesting that the decrease of FKBP52 detected in AD neurons might be relevant to the progression of the tauopathy [61]. Due to its involvement in several neuronal MT-dependent signaling pathways, FKBP52 overexpression can also have severe side effects as described by recent studies on different mouse models [147,148] pointing again to the importance of preserving normal FKBP52 expression levels in the brain for neuronal health. Nevertheless, FKBP52 is a highly expressed protein in brain neurons compared to glial cells [29] and its neuronal overexpression and specific contribution to neuronal homeostasis still remain to be analyzed. On the other hand, FKBP52 also binds $\mathrm{APP}$ and its overexpression decreases the toxicity associated with the transgenic expression of $A \beta$ peptides in Drosophila which is possibly due to the involvement of FKBP52 in A $\beta$ 
turnover [149]. This inverse effect of FKBP52 overexpression on A $\beta$ and Tau toxicity might be due to the level or the timescale of FKBP52 expression in these models.

\subsection{FKBP52 in Stress and Inflammation}

As previously described, FKBP52 is implicated in the retrograde transport and translocation of the hormone bound GR [57]. Abnormal FKBP52 decrease in AD and FTLD-Tau brain might also induce an imbalance in GR signaling and modulate glucocorticoid levels thus impacting on responses to stress and inflammation. Neuronal exposure to high levels of glucocorticoids is known to be a major risk factor of $\mathrm{AD}$ and various studies have shown that glucocorticoids cause abnormal Tau and $\mathrm{A} \beta$ accumulation leading to MT and synaptic dysfunction [150-152]. Upon ligand binding, GR is translocated to the nucleus with the help of FKBP52 regulating gene expression which may result in the inhibition of pro-inflammatory genes in glial cells [153]. Nuclear translocated GR is able to form heterocomplexes with Nf-kappaB, a transcription factor involved in the expression of various pro-inflammatory genes, to inhibit the biological response of Nf-kappaB through transrepression [59]. Hence, deregulated FKBP52 expression in glial cells might be involved in the disruption of the anti- and pro-inflammatory signaling balance resulting in chronic neuroinflammation and neuronal damage as observed in pathologically vulnerable regions of AD brain [154-156]. Another possible effect is FKBP52 interaction with Atox1 and it has been shown that FKBP52 overexpression increases rapid copper efflux in copper-treated cells suggesting that FKBP52 might protect neurons against copper toxicity [97]. Copper is a metal ion implicated in the pathogenesis of AD and PD $[157,158]$ and is an essential micronutrient that plays a fundamental role in innate and adaptive inflammation again suggesting a possible FKBP52 involvement in this process [99].

\section{Conclusions}

FKBP52 is a ubiquitously expressed and highly conserved protein that plays important roles in the MT environment. Various studies highlight its importance in several MTdependent signaling pathways such as protein transport, transcriptional regulation, protein aggregation and clearance, and suggest that FKBP52 plays a key role in neurite outgrowth, neuronal differentiation, inflammation, endocrine stress responses and cellular homeostasis. Given its involvement in MT signaling dynamics and protein aggregation, FKBP52 has been implicated in several neurodegenerative diseases such as AD and PD and represents a promising theranostic target in these pathologies. Our current knowledge tends to show that variations of brain FKBP52 expression contribute to the progression of Tau pathogenesis and points to the importance of preserving physiological FKBP52 expression levels for neuronal survival. FKBP52 also jointly acts with other members of the FKBP family as shown by the antagonistic action of FKBP52/FKBP51 in regulating MT dynamics and protein trafficking in neurons or by the cooperative effects of FKBPs in controlling Tau aggregation. Efforts to improve our understanding of the role and interplay of each FKBP in MT function and of their involvement in aggregation-prone protein accumulation and clearance would enhance our knowledge on their impact in the neurodegenerative processes. Deciphering the implications of FKBPs in neuronal homeostasis and pathology could assign them the role of therapeutic targets for the treatment of the neurodegenerative diseases linked to pathologic protein aggregation.

Author Contributions: Conceptualization: J.G., Writing—Original Draft Preparation: J.G., Writing—Review and Editing: All the authors, Supervision: E.E.B. and J.G. All authors have read and agreed to the published version of the manuscript.

Funding: The work is supported by Inserm and "Institut Professeur Baulieu", le Kremlin-Bicêtre, France.

Institutional Review Board Statement: Not applicable.

Informed Consent Statement: Not applicable.

Data Availability Statement: The data that support the findings are in the referenced studies. 
Conflicts of Interest: The authors have no conflict of interest to disclose.

\section{Abbreviations}

$\begin{array}{ll}\text { AD } & \text { Alzheimer disease } \\ \text { ALP } & \text { autophagy lysosomal pathway } \\ \text { APP } & \text { amyloid precursor protein } \\ \text { Atox1 } & \text { antioxidant protein 1 } \\ \text { A } \beta & \text { amyloid beta } \\ \text { ER } & \text { endoplasmic reticulum } \\ \text { FK1 } & \text { FK506 binding domain } 1 \\ \text { FKBPs } & \text { FK506-binding proteins } \\ \text { FTLD-Tau } & \text { frontotemporal lobar degeneration linked to a point-mutation of Tau gene } \\ \text { GR } & \text { glucocorticoid receptor } \\ \text { Hsp90 } & \text { heat shock protein of } 90 \text { kDa } \\ \text { hTERT } & \text { human telomerase reverse transcriptase } \\ \text { IRF4 } & \text { interferon regulating factor } \\ \text { MT } & \text { microtubule } \\ \text { Nf-kappaB } & \text { nuclear factor K-light chain enhancer of activated lymphocyte B cells } \\ \text { PD } & \text { Parkinson disease } \\ \text { PPIase } & \text { peptidyl-prolyl cis trans isomerase } \\ \text { SHR } & \text { steroid hormone receptor } \\ \text { Tau } & \text { tubulin associated unit } \\ \text { TPR } & \text { tetratricopeptide repeat } \\ \alpha \text {-syn } & \text { alpha-synuclein }\end{array}$

\section{References}

1. Schiene, C.; Fischer, G. Enzymes that catalyse the restructuring of proteins. Curr. Opin. Struct. Biol. 2000, 10, 40-45. [CrossRef]

2. Wedemeyer, W.J.; Welker, E.; Scheraga, H.A. Proline cis-trans isomerization and protein folding. Biochemistry 2002, 41, 14637-14644. [CrossRef] [PubMed]

3. Chambraud, B.; Rouviere-Fourmy, N.; Radanyi, C.; Hsiao, K.; Peattie, D.A.; Livingston, D.J.; Baulieu, E.E. Overexpression of p59-HBI (FKBP90), full length and domains, and characterization of PPlase activity. Biochem. Biophys. Res. Commun. 1993, 196, 160-166. [CrossRef] [PubMed]

4. Schreiber, S.L. Chemistry and biology of the immunophilins and their immunosuppressive ligands. Science 1991, 251, 283-287. [CrossRef] [PubMed]

5. Harding, M.W.; Galat, A.; Uehling, D.E.; Schreiber, S.L. A receptor for the immunosuppressant FK506 is a cis-trans peptidyl-prolyl isomerase. Nature 1989, 341, 758-760. [CrossRef] [PubMed]

6. Steiner, J.P.; Dawson, T.M.; Fotuhi, M.; Glatt, C.E.; Snowman, A.M.; Cohen, N.; Snyder, S.H. High brain densities of the immunophilin FKBP colocalized with calcineurin. Nature 1992, 358, 584-587. [CrossRef] [PubMed]

7. Snyder, S.H.; Sabatini, D.M. Immunophilins and the nervous system. Nat. Med. 1995, 1, 32-37. [CrossRef]

8. Storer, C.L.; Dickey, C.A.; Galigniana, M.D.; Rein, T.; Cox, M.B. FKBP51 and FKBP52 in signaling and disease. Trends Endocrinol. Metab. TEM 2011, 22, 481-490. [CrossRef]

9. Guy, N.C.; Garcia, Y.A.; Sivils, J.C.; Galigniana, M.D.; Cox, M.B. Functions of the Hsp90-binding FKBP immunophilins. Sub-Cell. Biochem. 2015, 78, 35-68. [CrossRef]

10. Hong, C.; Li, T.; Zhang, F.; Wu, X.; Chen, X.; Cui, X.; Zhang, G.; Cui, Y. Elevated FKBP52 expression indicates a poor outcome in patients with breast cancer. Oncol. Lett. 2017, 14, 5379-5385. [CrossRef]

11. Maeda, K.; Habara, M.; Kawaguchi, M.; Matsumoto, H.; Hanaki, S.; Masaki, T.; Sato, Y.; Matsuyama, H.; Kunieda, K.; Nakagawa, H.; et al. FKBP51 and FKBP52 regulate androgen receptor dimerization and proliferation in prostate cancer cells. Mol. Oncol. 2021. [CrossRef] [PubMed]

12. Chambraud, B.; Sardin, E.; Giustiniani, J.; Dounane, O.; Schumacher, M.; Goedert, M.; Baulieu, E.E. A role for FKBP52 in Tau protein function. Proc. Natl. Acad. Sci. USA 2010, 107, 2658-2663. [CrossRef] [PubMed]

13. Gerard, M.; Deleersnijder, A.; Daniels, V.; Schreurs, S.; Munck, S.; Reumers, V.; Pottel, H.; Engelborghs, Y.; Van den Haute, C.; Taymans, J.M.; et al. Inhibition of FK506 binding proteins reduces alpha-synuclein aggregation and Parkinson's disease-like pathology. J. Neurosci. Off. J. Soc. Neurosci. 2010, 30, 2454-2463. [CrossRef]

14. Fusco, D.; Vargiolu, M.; Vidone, M.; Mariani, E.; Pennisi, L.F.; Bonora, E.; Capellari, S.; Dirnberger, D.; Baumeister, R.; Martinelli, P.; et al. The RET51/FKBP52 complex and its involvement in Parkinson disease. Hum. Mol. Genet. 2010, 19, 2804-2816. [CrossRef]

15. Siekierka, J.J.; Hung, S.H.; Poe, M.; Lin, C.S.; Sigal, N.H. A cytosolic binding protein for the immunosuppressant FK506 has peptidyl-prolyl isomerase activity but is distinct from cyclophilin. Nature 1989, 341, 755-757. [CrossRef] [PubMed] 
16. Avramut, M.; Achim, C.L. Immunophilins and their ligands: Insights into survival and growth of human neurons. Physiol. Behav. 2002, 77, 463-468. [CrossRef]

17. Nigam, S.K.; Jin, Y.J.; Jin, M.J.; Bush, K.T.; Bierer, B.E.; Burakoff, S.J. Localization of the FK506-binding protein, FKBP 13, to the lumen of the endoplasmic reticulum. Biochem. J. 1993, 294, 511-515. [CrossRef]

18. Tremmel, D.; Tropschug, M. Neurospora crassa FKBP22 is a novel er chaperone and functionally cooperates with BiP. J. Mol. Biol. 2007, 369, 55-68. [CrossRef]

19. Patterson, C.E.; Schaub, T.; Coleman, E.J.; Davis, E.C. Developmental regulation of FKBP65. An er-localized extracellular matrix binding-protein. Mol. Biol. Cell 2000, 11, 3925-3935. [CrossRef]

20. Jin, Y.J.; Albers, M.W.; Lane, W.S.; Bierer, B.E.; Schreiber, S.L.; Burakoff, S.J. Molecular cloning of a membrane-associated human FK506- and rapamycin-binding protein, FKBP-13. Proc. Natl. Acad. Sci. USA 1991, 88, 6677-6681. [CrossRef]

21. Rulten, S.L.; Kinloch, R.A.; Tateossian, H.; Robinson, C.; Gettins, L.; Kay, J.E. The human FK506-binding proteins: Characterization of human FKBP19. Mamm. Genome Off. J. Int. Mamm. Genome Soc. 2006, 17, 322-331. [CrossRef] [PubMed]

22. Baumann, M.; Giunta, C.; Krabichler, B.; Ruschendorf, F.; Zoppi, N.; Colombi, M.; Bittner, R.E.; Quijano-Roy, S.; Muntoni, F.; Cirak, S.; et al. Mutations in FKBP14 cause a variant of Ehlers-Danlos syndrome with progressive kyphoscoliosis, myopathy, and hearing loss. Am. J. Hum. Genet. 2012, 90, 201-216. [CrossRef] [PubMed]

23. Nakamura, T.; Yabe, D.; Kanazawa, N.; Tashiro, K.; Sasayama, S.; Honjo, T. Molecular cloning, characterization, and chromosomal localization of fkbp23, a novel FK506-binding protein with $\mathrm{Ca}^{2+}$-binding ability. Genomics 1998, 54, 89-98. [CrossRef]

24. Riviere, S.; Menez, A.; Galat, A. On the localization of FKBP25 in T-lymphocytes. FEBS Lett. 1993, 315, 247-251. [CrossRef]

25. Galigniana, M.D.; Echeverria, P.C.; Erlejman, A.G.; Piwien-Pilipuk, G. Role of molecular chaperones and TPR-domain proteins in the cytoplasmic transport of steroid receptors and their passage through the nuclear pore. Nucleus 2010, 1, 299-308. [CrossRef] [PubMed]

26. Helander, S.; Montecchio, M.; Lemak, A.; Fares, C.; Almlof, J.; Yi, Y.; Yee, A.; Arrowsmith, C.; DhePaganon, S.; Sunnerhagen, M. Basic tilted helix bundle - a new protein fold in human FKBP25/FKBP3 and HectD1. Biochem. Biophys. Res. Commun. 2014, 447, 26-31. [CrossRef] [PubMed]

27. Nakajima, O.; Nakamura, F.; Yamashita, N.; Tomita, Y.; Suto, F.; Okada, T.; Iwamatsu, A.; Kondo, E.; Fujisawa, H.; Takei, K.; et al. FKBP133: A novel mouse FK506-binding protein homolog alters growth cone morphology. Biochem. Biophys. Res. Commun. 2006, 346, 140-149. [CrossRef] [PubMed]

28. Gallo, L.I.; Lagadari, M.; Piwien-Pilipuk, G.; Galigniana, M.D. The 90-kda heat-shock protein (Hsp90)-binding immunophilin $\mathrm{fkbp} 51$ is a mitochondrial protein that translocates to the nucleus to protect cells against oxidative stress. J. Biol. Chem. 2011, 286, 30152-30160. [CrossRef]

29. Meduri, G.; Guillemeau, K.; Dounane, O.; Sazdovitch, V.; Duyckaerts, C.; Chambraud, B.; Baulieu, E.E.; Giustiniani, J. Caspasecleaved tau-d(421) is colocalized with the immunophilin FKBP52 in the autophagy-endolysosomal system of Alzheimer's disease neurons. Neurobiol. Aging 2016, 46, 124-137. [CrossRef]

30. Perrot-Applanat, M.; Cibert, C.; Geraud, G.; Renoir, J.M.; Baulieu, E.E. The 59 kda FK506-binding protein, a 90 kda heat shock protein binding immunophilin (FKBP59-HBI), is associated with the nucleus, the cytoskeleton and mitotic apparatus. J. Cell Sci. 1995, 108, 2037-2051. [CrossRef]

31. Chambraud, B.; Belabes, H.; Fontaine-Lenoir, V.; Fellous, A.; Baulieu, E.E. The immunophilin FKBP52 specifically binds to tubulin and prevents microtubule formation. FASEB J. Off. Publ. Fed. Am. Soc. Exp. Biol. 2007, 21, 2787-2797. [CrossRef] [PubMed]

32. Dilworth, D.; Gudavicius, G.; Xu, X.; Boyce, A.K.J.; O'Sullivan, C.; Serpa, J.J.; Bilenky, M.; Petrochenko, E.V.; Borchers, C.H.; Hirst, M.; et al. The prolyl isomerase FKBP25 regulates microtubule polymerization impacting cell cycle progression and genomic stability. Nucleic Acids Res. 2018, 46, 2459-2478. [CrossRef] [PubMed]

33. Ikura, T.; Ito, N. Peptidyl-prolyl isomerase activity of FK506 binding protein 12 prevents tau peptide from aggregating Protein Eng. Des. Sel. PEDS 2013, 26, 539-546. [CrossRef] [PubMed]

34. Liu, F.L.; Liu, T.Y.; Kung, F.L. FKBP12 regulates the localization and processing of amyloid precursor protein in human cell lines. J. Biosci. 2014, 39, 85-95. [CrossRef]

35. Gant, J.C.; Blalock, E.M.; Chen, K.C.; Kadish, I.; Porter, N.M.; Norris, C.M.; Thibault, O.; Landfield, P.W. FK506-binding protein 1b/12.6: A key to aging-related hippocampal $\mathrm{Ca}^{2+}$ dysregulation? Eur. J. Pharmacol. 2014, 739, 74-82. [CrossRef]

36. Ochocka, A.M.; Kampanis, P.; Nicol, S.; Allende-Vega, N.; Cox, M.; Marcar, L.; Milne, D.; Fuller-Pace, F.; Meek, D. FKBP25, a novel regulator of the p53 pathway, induces the degradation of MDM2 and activation of p53. FEBS Lett. 2009, 583, 621-626. [CrossRef]

37. Bailus, B.J.; Scheeler, S.M.; Simons, J.; Sanchez, M.A.; Tshilenge, K.T.; Creus-Muncunill, J.; Naphade, S.; Lopez-Ramirez, A.; Zhang, N.; Lakshika Madushani, K.; et al. Modulating FKBP5/FKBP51 and autophagy lowers HTT (huntingtin) levels. Autophagy 2021, 17, 4119-4140. [CrossRef]

38. Jarczowski, F.; Fischer, G.; Edlich, F. FKBP36 forms complexes with clathrin and Hsp72 in spermatocytes. Biochemistry 2008, 47, 6946-6952. [CrossRef]

39. Francke, U. Williams-Beuren syndrome: Genes and mechanisms. Hum. Mol. Genet. 1999, 8, 1947-1954. [CrossRef]

40. Zhang, X.; Wang, Y.; Li, H.; Zhang, W.; Wu, D.; Mi, H. The mouse FKBP23 binds to bip in er and the binding of c-terminal domain is interrelated with $\mathrm{Ca}^{2+}$ concentration. FEBS Lett. 2004, 559, 57-60. [CrossRef]

41. Bai, X.; Ma, D.; Liu, A.; Shen, X.; Wang, Q.J.; Liu, Y.; Jiang, Y. Rheb activates mTOR by antagonizing its endogenous inhibitor, FKBP38. Science 2007, 318, 977-980. [CrossRef] 
42. Brown, C.A.; Schmidt, C.; Poulter, M.; Hummerich, H.; Klohn, P.C.; Jat, P.; Mead, S.; Collinge, J.; Lloyd, S.E. In vitro screen of prion disease susceptibility genes using the scrapie cell assay. Hum. Mol. Genet. 2014, 23, 5102-5108. [CrossRef] [PubMed]

43. Sezen, S.F.; Lagoda, G.; Burnett, A.L. Role of immunophilins in recovery of erectile function after cavernous nerve injury. J. Sex. Med. 2009, 6 (Suppl 3), 340-346. [CrossRef]

44. Alanay, Y.; Avaygan, H.; Camacho, N.; Utine, G.E.; Boduroglu, K.; Aktas, D.; Alikasifoglu, M.; Tuncbilek, E.; Orhan, D.; Bakar, F.T.; et al. Mutations in the gene encoding the RER protein FKBP65 cause autosomal-recessive osteogenesis imperfecta. Am. J. Hum. Genet. 2010, 86, 551-559. [CrossRef] [PubMed]

45. van de Hoef, D.L.; Hughes, J.; Livne-Bar, I.; Garza, D.; Konsolaki, M.; Boulianne, G.L. Identifying genes that interact with Drosophila presenilin and amyloid precursor protein. Genesis 2009, 47, 246-260. [CrossRef]

46. Jarczowski, F.; Jahreis, G.; Erdmann, F.; Schierhorn, A.; Fischer, G.; Edlich, F. FKBP36 is an inherent multifunctional glyceraldehyde3-phosphate dehydrogenase inhibitor. J. Biol. Chem. 2009, 284, 766-773. [CrossRef] [PubMed]

47. Shirane, M.; Nakayama, K.I. Inherent calcineurin inhibitor FKBP38 targets Bcl-2 to mitochondria and inhibits apoptosis. Nat. Cell Biol. 2003, 5, 28-37. [CrossRef]

48. Hahle, A.; Merz, S.; Meyners, C.; Hausch, F. The many faces of FKBP51. Biomolecules 2019, 9, 35. [CrossRef]

49. Linnert, M.; Lin, Y.J.; Manns, A.; Haupt, K.; Paschke, A.K.; Fischer, G.; Weiwad, M.; Lucke, C. The FKBP-type domain of the human aryl hydrocarbon receptor-interacting protein reveals an unusual Hsp90 interaction. Biochemistry 2013, 52, $2097-2107$. [CrossRef]

50. McKeen, H.D.; McAlpine, K.; Valentine, A.; Quinn, D.J.; McClelland, K.; Byrne, C.; O’Rourke, M.; Young, S.; Scott, C.J.; McCarthy, H.O.; et al. A novel FKBP-like binding protein interacts with the glucocorticoid receptor and regulates steroid receptor signaling. Endocrinology 2008, 149, 5724-5734. [CrossRef]

51. Gerard, M.; Debyser, Z.; Desender, L.; Baert, J.; Brandt, I.; Baekelandt, V.; Engelborghs, Y. FK506 binding protein 12 differentially accelerates fibril formation of wild type alpha-synuclein and its clinical mutants A30P or A53T. J. Neurochem. 2008, 106, 121-133. [CrossRef] [PubMed]

52. Deleersnijder, A.; Van Rompuy, A.S.; Desender, L.; Pottel, H.; Buee, L.; Debyser, Z.; Baekelandt, V.; Gerard, M. Comparative analysis of different peptidyl-prolyl isomerases reveals FK506-binding protein 12 as the most potent enhancer of alpha-synuclein aggregation. J. Biol. Chem. 2011, 286, 26687-26701. [CrossRef] [PubMed]

53. Sugata, H.; Matsuo, K.; Nakagawa, T.; Takahashi, M.; Mukai, H.; Ono, Y.; Maeda, K.; Akiyama, H.; Kawamata, T. A peptidyl-prolyl isomerase, FKBP12, accumulates in alzheimer neurofibrillary tangles. Neurosci. Lett 2009, 459, 96-99. [CrossRef] [PubMed]

54. Giustiniani, J.; Chambraud, B.; Sardin, E.; Dounane, O.; Guillemeau, K.; Nakatani, H.; Paquet, D.; Kamah, A.; Landrieu, I.; Lippens, G.; et al. Immunophilin FKBP52 induces Tau-P301L filamentous assembly in vitro and modulates its activity in a model of tauopathy. Proc. Natl. Acad. Sci. USA 2014, 111, 4584-4589. [CrossRef] [PubMed]

55. Giustiniani, J.; Guillemeau, K.; Dounane, O.; Sardin, E.; Huvent, I.; Schmitt, A.; Hamdane, M.; Buee, L.; Landrieu, I.; Lippens, G.; et al. The FK506-binding protein FKBP52 in vitro induces aggregation of truncated tau forms with prion-like behavior. FASEB J. Off. Publ. Fed. Am. Soc. Exp. Biol. 2015, 29, 3171-3181. [CrossRef]

56. Kamah, A.; Cantrelle, F.X.; Huvent, I.; Giustiniani, J.; Guillemeau, K.; Byrne, C.; Jacquot, Y.; Landrieu, I.; Baulieu, E.E.; Smet, C.; et al. Isomerization and oligomerization of truncated and mutated tau forms by FKBP52 are independent processes. J. Mol. Biol. 2016, 428, 1080-1090. [CrossRef] [PubMed]

57. Tatro, E.T.; Everall, I.P.; Kaul, M.; Achim, C.L. Modulation of glucocorticoid receptor nuclear translocation in neurons by immunophilins FKBP51 and FKBP52: Implications for major depressive disorder. Brain Res. 2009, 1286, 1-12. [CrossRef] [PubMed]

58. Jeong, Y.Y.; Her, J.; Oh, S.Y.; Chung, I.K. Hsp90-binding immunophilin FKBP52 modulates telomerase activity by promoting the cytoplasmic retrotransport of htert. Biochem. J. 2016, 473, 3517-3532. [CrossRef]

59. Erlejman, A.G.; De Leo, S.A.; Mazaira, G.I.; Molinari, A.M.; Camisay, M.F.; Fontana, V.; Cox, M.B.; Piwien-Pilipuk, G.; Galigniana, M.D. Nf-kappab transcriptional activity is modulated by FK506-binding proteins FKBP51 and FKBP52: A role for peptidyl-prolyl isomerase activity. J. Biol. Chem. 2014, 289, 26263-26276. [CrossRef]

60. Mamane, Y.; Sharma, S.; Petropoulos, L.; Lin, R.; Hiscott, J. Posttranslational regulation of IRF-4 activity by the immunophilin FKBP52. Immunity 2000, 12, 129-140. [CrossRef]

61. Chambraud, B.; Daguinot, C.; Guillemeau, K.; Genet, M.; Dounane, O.; Meduri, G.; Pous, C.; Baulieu, E.E.; Giustiniani, J. Decrease of neuronal FKBP4/FKBP52 modulates perinuclear lysosomal positioning and mapt/tau behavior during mapt/tau-induced proteotoxic stress. Autophagy 2021, 17, 3491-3510. [CrossRef]

62. Blair, L.J.; Baker, J.D.; Sabbagh, J.J.; Dickey, C.A. The emerging role of peptidyl-prolyl isomerase chaperones in tau oligomerization, amyloid processing, and Alzheimer's disease. J. Neurochem. 2015, 133, 1-13. [CrossRef]

63. Jinwal, U.K.; Koren, J., 3rd; Borysov, S.I.; Schmid, A.B.; Abisambra, J.F.; Blair, L.J.; Johnson, A.G.; Jones, J.R.; Shults, C.L.; O'Leary, J.C., 3rd; et al. The Hsp90 cochaperone, FKBP51, increases tau stability and polymerizes microtubules. J. Neurosci. Off. J. Soc. Neurosci. 2010, 30, 591-599. [CrossRef]

64. Lagadari, M.; Zgajnar, N.R.; Gallo, L.I.; Galigniana, M.D. Hsp90-binding immunophilin FKBP51 forms complexes with htert enhancing telomerase activity. Mol. Oncol. 2016, 10, 1086-1098. [CrossRef]

65. Gassen, N.C.; Hartmann, J.; Schmidt, M.V.; Rein, T. FKBP5/FKBP51 enhances autophagy to synergize with antidepressant action. Autophagy 2015, 11, 578-580. [CrossRef] [PubMed] 
66. Bhujabal, Z.; Birgisdottir, A.B.; Sjottem, E.; Brenne, H.B.; Overvatn, A.; Habisov, S.; Kirkin, V.; Lamark, T.; Johansen, T. FKBP8 recruits LC3A to mediate parkin-independent mitophagy. EMBO Rep. 2017, 18, 947-961. [CrossRef]

67. Viklund, I.M.; Aspenstrom, P.; Meas-Yedid, V.; Zhang, B.; Kopec, J.; Agren, D.; Schneider, G.; D'Amato, M.; Olivo-Marin, J.C.; Sansonetti, P.; et al. WAFL, a new protein involved in regulation of early endocytic transport at the intersection of actin and microtubule dynamics. Exp. Cell Res. 2009, 315, 1040-1052. [CrossRef] [PubMed]

68. Wu, B.; Li, P.; Liu, Y.; Lou, Z.; Ding, Y.; Shu, C.; Ye, S.; Bartlam, M.; Shen, B.; Rao, Z. 3d structure of human FK506-binding protein 52: Implications for the assembly of the glucocorticoid receptor/Hsp90/immunophilin heterocomplex. Proc. Natl. Acad. Sci. USA 2004, 101, 8348-8353. [CrossRef] [PubMed]

69. Massol, N.; Lebeau, M.C.; Renoir, J.M.; Faber, L.E.; Baulieu, E.E. Rabbit FKBP59-heat shock protein binding immunophillin (HBI) is a calmodulin binding protein. Biochem. Biophys. Res. Commun. 1992, 187, 1330-1335. [CrossRef]

70. Le Bihan, S.; Renoir, J.M.; Radanyi, C.; Chambraud, B.; Joulin, V.; Catelli, M.G.; Baulieu, E.E. The mammalian heat shock protein binding immunophilin (p59/HBI) is an ATP and GTP binding protein. Biochem. Biophys. Res. Commun. 1993, 195, 600-607. [CrossRef] [PubMed]

71. Bose, S.; Weikl, T.; Bugl, H.; Buchner, J. Chaperone function of Hsp90-associated proteins. Science 1996, 274, 1715-1717. [CrossRef] [PubMed]

72. Radanyi, C.; Chambraud, B.; Baulieu, E.E. The ability of the immunophilin FKBP59-HBI to interact with the 90-kda heat shock protein is encoded by its tetratricopeptide repeat domain. Proc. Natl. Acad. Sci. USA 1994, 91, 11197-11201. [CrossRef] [PubMed]

73. Kelliher, M.T.; Saunders, H.A.; Wildonger, J. Microtubule control of functional architecture in neurons. Curr. Opin. Neurobiol. 2019, 57, 39-45. [CrossRef]

74. Janke, C.; Bulinski, J.C. Post-translational regulation of the microtubule cytoskeleton: Mechanisms and functions. Nat. Rev. Mol. Cell Biol. 2011, 12, 773-786. [CrossRef] [PubMed]

75. Tai, P.K.; Maeda, Y.; Nakao, K.; Wakim, N.G.; Duhring, J.L.; Faber, L.E. A 59-kilodalton protein associated with progestin, estrogen, androgen, and glucocorticoid receptors. Biochemistry 1986, 25, 5269-5275. [CrossRef]

76. Renoir, J.M.; Radanyi, C.; Jung-Testas, I.; Faber, L.E.; Baulieu, E.E. The nonactivated progesterone receptor is a nuclear heterooligomer. J. Biol. Chem. 1990, 265, 14402-14406. [CrossRef]

77. Silverstein, A.M.; Galigniana, M.D.; Kanelakis, K.C.; Radanyi, C.; Renoir, J.M.; Pratt, W.B. Different regions of the immunophilin FKBP52 determine its association with the glucocorticoid receptor, Hsp90, and cytoplasmic dynein. J. Biol. Chem. 1999, 274, 36980-36986. [CrossRef]

78. Sinars, C.R.; Cheung-Flynn, J.; Rimerman, R.A.; Scammell, J.G.; Smith, D.F.; Clardy, J. Structure of the large FK506-binding protein FKBP51, an Hsp90-binding protein and a component of steroid receptor complexes. Proc. Natl. Acad. Sci. USA 2003, 100, 868-873. [CrossRef]

79. Mustafi, S.M.; LeMaster, D.M.; Hernandez, G. Differential conformational dynamics in the closely homologous FK506-binding domains of FKBP51 and FKBP52. Biochem. J. 2014, 461, 115-123. [CrossRef]

80. Wochnik, G.M.; Ruegg, J.; Abel, G.A.; Schmidt, U.; Holsboer, F.; Rein, T. FK506-binding proteins 51 and 52 differentially regulate dynein interaction and nuclear translocation of the glucocorticoid receptor in mammalian cells. J. Biol. Chem. 2005, 280, 4609-4616. [CrossRef]

81. Quinta, H.R.; Galigniana, M.D. The neuroregenerative mechanism mediated by the hsp90-binding immunophilin FKBP52 resembles the early steps of neuronal differentiation. Br. J. Pharmacol. 2012, 166, 637-649. [CrossRef]

82. Shim, S.; Yuan, J.P.; Kim, J.Y.; Zeng, W.; Huang, G.; Milshteyn, A.; Kern, D.; Muallem, S.; Ming, G.L.; Worley, P.F. Peptidyl-prolyl isomerase FKBP52 controls chemotropic guidance of neuronal growth cones via regulation of TRPC1 channel opening. Neuron 2009, 64, 471-483. [CrossRef] [PubMed]

83. O’Brien, E.T.; Salmon, E.D.; Erickson, H.P. How calcium causes microtubule depolymerization. Cell Motil. Cytoskelet. 1997, 36, 125-135. [CrossRef]

84. Bandleon, S.; Strunz, P.P.; Pickel, S.; Tiapko, O.; Cellini, A.; Miranda-Laferte, E.; Eder-Negrin, P. FKBP52 regulates TRPC3dependent $\mathrm{Ca}^{2+}$ signals and the hypertrophic growth of cardiomyocyte cultures. J. Cell Sci. 2019, 132. [CrossRef] [PubMed]

85. Gkika, D.; Topala, C.N.; Hoenderop, J.G.; Bindels, R.J. The immunophilin FKBP52 inhibits the activity of the epithelial Ca ${ }^{2+}$ channel TRPV5. Am. J. Physiol. Ren. Physiol. 2006, 290, F1253-F1259. [CrossRef] [PubMed]

86. Galigniana, M.D.; Radanyi, C.; Renoir, J.M.; Housley, P.R.; Pratt, W.B. Evidence that the peptidylprolyl isomerase domain of the Hsp90-binding immunophilin FKBP52 is involved in both dynein interaction and glucocorticoid receptor movement to the nucleus. J. Biol. Chem. 2001, 276, 14884-14889. [CrossRef] [PubMed]

87. Gallo, L.I.; Ghini, A.A.; Piwien Pilipuk, G.; Galigniana, M.D. Differential recruitment of tetratricorpeptide repeat domain immunophilins to the mineralocorticoid receptor influences both heat-shock protein 90-dependent retrotransport and hormonedependent transcriptional activity. Biochemistry 2007, 46, 14044-14057. [CrossRef]

88. Garabedian, M.J.; Harris, C.A.; Jeanneteau, F. Glucocorticoid receptor action in metabolic and neuronal function. F1000Research 2017, 6, 1208. [CrossRef]

89. Allan, R.K.; Ratajczak, T. Versatile tpr domains accommodate different modes of target protein recognition and function. Cell Stress Chaperones 2011, 16, 353-367. [CrossRef]

90. Ratajczak, T.; Cluning, C.; Ward, B.K. Steroid receptor-associated immunophilins: A gateway to steroid signalling. The Clin. Biochem. Rev. 2015, 36, 31-52. 
91. Zgajnar, N.R.; De Leo, S.A.; Lotufo, C.M.; Erlejman, A.G.; Piwien-Pilipuk, G.; Galigniana, M.D. Biological actions of the Hsp90-binding immunophilins FKBP51 and FKBP52. Biomolecules 2019, 9, 52. [CrossRef] [PubMed]

92. Tak, P.P.; Firestein, G.S. NF-kappaB: A key role in inflammatory diseases. J. Clin. Investig. 2001, 107, 7-11. [CrossRef] [PubMed]

93. Liu, T.; Zhang, L.; Joo, D.; Sun, S.C. NF-kappaB signaling in inflammation. Signal Transduct. Target. Ther. 2017, 2, 17023. [CrossRef] [PubMed]

94. Annett, S.; Moore, G.; Robson, T. FK506 binding proteins and inflammation related signalling pathways; basic biology, current status and future prospects for pharmacological intervention. Pharmacol. Ther. 2020, 215, 107623. [CrossRef]

95. Mikenberg, I.; Widera, D.; Kaus, A.; Kaltschmidt, B.; Kaltschmidt, C. Transcription factor nf-kappab is transported to the nucleus via cytoplasmic dynein/dynactin motor complex in hippocampal neurons. PloS ONE 2007, 2, e589. [CrossRef] [PubMed]

96. Guo, S.; Li, Z.Z.; Jiang, D.S.; Lu, Y.Y.; Liu, Y.; Gao, L.; Zhang, S.M.; Lei, H.; Zhu, L.H.; Zhang, X.D.; et al. IRF4 is a novel mediator for neuronal survival in ischaemic stroke. Cell Death Differ. 2014, 21, 888-903. [CrossRef]

97. Sanokawa-Akakura, R.; Dai, H.; Akakura, S.; Weinstein, D.; Fajardo, J.E.; Lang, S.E.; Wadsworth, S.; Siekierka, J.; Birge, R.B. A novel role for the immunophilin FKBP52 in copper transport. J. Biol. Chem. 2004, 279, 27845-27848. [CrossRef]

98. Lim, C.M.; Cater, M.A.; Mercer, J.F.; La Fontaine, S. Copper-dependent interaction of dynactin subunit p62 with the $\mathrm{n}$ terminus of ATP7B but not ATP7A. J. Biol. Chem. 2006, 281, 14006-14014. [CrossRef]

99. Chen, G.F.; Sudhahar, V.; Youn, S.W.; Das, A.; Cho, J.; Kamiya, T.; Urao, N.; McKinney, R.D.; Surenkhuu, B.; Hamakubo, T.; et al. Copper transport protein antioxidant-1 promotes inflammatory neovascularization via chaperone and transcription factor function. Sci. Rep. 2015, 5, 14780. [CrossRef]

100. Giannakakou, P.; Sackett, D.L.; Ward, Y.; Webster, K.R.; Blagosklonny, M.V.; Fojo, T. P53 is associated with cellular microtubules and is transported to the nucleus by dynein. Nat. Cell Biol. 2000, 2, 709-717. [CrossRef]

101. Galigniana, M.D.; Harrell, J.M.; O’Hagen, H.M.; Ljungman, M.; Pratt, W.B. Hsp90-binding immunophilins link p53 to dynein during p53 transport to the nucleus. J. Biol. Chem. 2004, 279, 22483-22489. [CrossRef] [PubMed]

102. Harada, A.; Takei, Y.; Kanai, Y.; Tanaka, Y.; Nonaka, S.; Hirokawa, N. Golgi vesiculation and lysosome dispersion in cells lacking cytoplasmic dynein. J. Cell Biol. 1998, 141, 51-59. [CrossRef] [PubMed]

103. Weingarten, M.D.; Lockwood, A.H.; Hwo, S.Y.; Kirschner, M.W. A protein factor essential for microtubule assembly. Proc. Natl. Acad. Sci. USA 1975, 72, 1858-1862. [CrossRef]

104. Kadavath, H.; Hofele, R.V.; Biernat, J.; Kumar, S.; Tepper, K.; Urlaub, H.; Mandelkow, E.; Zweckstetter, M. Tau stabilizes microtubules by binding at the interface between tubulin heterodimers. Proc. Natl. Acad. Sci. USA 2015, 112, 7501-7506. [CrossRef] [PubMed]

105. Alim, M.A.; Ma, Q.L.; Takeda, K.; Aizawa, T.; Matsubara, M.; Nakamura, M.; Asada, A.; Saito, T.; Kaji, H.; Yoshii, M.; et al. Demonstration of a role for alpha-synuclein as a functional microtubule-associated protein. J. Alzheimer's Dis. JAD 2004, 6, 435-442; discussion 443-449. [CrossRef] [PubMed]

106. Cartelli, D.; Aliverti, A.; Barbiroli, A.; Santambrogio, C.; Ragg, E.M.; Casagrande, F.V.; Cantele, F.; Beltramone, S.; Marangon, J.; De Gregorio, C.; et al. Alpha-synuclein is a novel microtubule dynamase. Sci Rep 2016, 6, 33289. [CrossRef] [PubMed]

107. Stamer, K.; Vogel, R.; Thies, E.; Mandelkow, E.; Mandelkow, E.M. Tau blocks traffic of organelles, neurofilaments, and app vesicles in neurons and enhances oxidative stress. J. Cell Biol. 2002, 156, 1051-1063. [CrossRef]

108. Eisbach, S.E.; Outeiro, T.F. Alpha-synuclein and intracellular trafficking: Impact on the spreading of parkinson's disease pathology. J. Mol. Med. 2013, 91, 693-703. [CrossRef]

109. Carnwath, T.; Mohammed, R.; Tsiang, D. The direct and indirect effects of alpha-synuclein on microtubule stability in the pathogenesis of Parkinson's disease. Neuropsychiatr. Dis. Treat. 2018, 14, 1685-1695. [CrossRef]

110. Grundke-Iqbal, I.; Iqbal, K.; Tung, Y.C.; Quinlan, M.; Wisniewski, H.M.; Binder, L.I. Abnormal phosphorylation of the microtubuleassociated protein tau (tau) in alzheimer cytoskeletal pathology. Proc. Natl. Acad. Sci. USA 1986, 83, 4913-4917. [CrossRef]

111. Gotz, J.; Ittner, L.M.; Fandrich, M.; Schonrock, N. Is tau aggregation toxic or protective: A sensible question in the absence of sensitive methods? J. Alzheimer's Dis. JAD 2008, 14, 423-429. [CrossRef]

112. Kopito, R.R. Ron r. Kopito: Unfolding the secrets of protein aggregation. Trends Cell Biol. 2016, 26, 559-560. [CrossRef] [PubMed]

113. Fassler, J.S.; Skuodas, S.; Weeks, D.L.; Phillips, B.T. Protein aggregation and disaggregation in cells and development. . J. Mol. Biol. 2021, 433, 167215. [CrossRef] [PubMed]

114. Blair, L.J.; Nordhues, B.A.; Hill, S.E.; Scaglione, K.M.; O’Leary, J.C., 3rd; Fontaine, S.N.; Breydo, L.; Zhang, B.; Li, P.; Wang, L.; et al. Accelerated neurodegeneration through chaperone-mediated oligomerization of tau. J. Clin. Investig. 2013, 123, 4158-4169. [CrossRef] [PubMed]

115. Weickert, S.; Wawrzyniuk, M.; John, L.H.; Rudiger, S.G.D.; Drescher, M. The mechanism of Hsp90-induced oligomerizaton of tau. Sci. Adv. 2020, 6, eaax6999. [CrossRef]

116. Karagoz, G.E.; Duarte, A.M.; Akoury, E.; Ippel, H.; Biernat, J.; Moran Luengo, T.; Radli, M.; Didenko, T.; Nordhues, B.A.; Veprintsev, D.B.; et al. Hsp90-tau complex reveals molecular basis for specificity in chaperone action. Cell 2014, 156, 963-974. [CrossRef]

117. Liberek, K.; Lewandowska, A.; Zietkiewicz, S. Chaperones in control of protein disaggregation. EMBO J. 2008, $27,328-335$. [CrossRef] 
118. Mok, S.A.; Condello, C.; Freilich, R.; Gillies, A.; Arhar, T.; Oroz, J.; Kadavath, H.; Julien, O.; Assimon, V.A.; Rauch, J.N.; et al. Mapping interactions with the chaperone network reveals factors that protect against tau aggregation. Nat. Struct. Mol. Biol. 2018, 25, 384-393. [CrossRef]

119. Salminen, A.; Ojala, J.; Kaarniranta, K.; Hiltunen, M.; Soininen, H. Hsp90 regulates tau pathology through co-chaperone complexes in Alzheimer's disease. Prog. Neurobiol. 2011, 93, 99-110. [CrossRef]

120. Daturpalli, S.; Waudby, C.A.; Meehan, S.; Jackson, S.E. Hsp90 inhibits alpha-synuclein aggregation by interacting with soluble oligomers. J. Mol. Biol. 2013, 425, 4614-4628. [CrossRef]

121. Jia, C.; Ma, X.; Liu, Z.; Gu, J.; Zhang, X.; Li, D.; Zhang, S. Different heat shock proteins bind alpha-synuclein with distinct mechanisms and synergistically prevent its amyloid aggregation. Front. Neurosci. 2019, 13, 1124. [CrossRef] [PubMed]

122. Wang, Y.; Martinez-Vicente, M.; Kruger, U.; Kaushik, S.; Wong, E.; Mandelkow, E.M.; Cuervo, A.M.; Mandelkow, E. Tau fragmentation, aggregation and clearance: The dual role of lysosomal processing. Hum. Mol. Genet. 2009, 18, 4153-4170. [CrossRef] [PubMed]

123. Mak, S.K.; McCormack, A.L.; Manning-Bog, A.B.; Cuervo, A.M.; Di Monte, D.A. Lysosomal degradation of alpha-synuclein in vivo. J. Biol. Chem. 2010, 285, 13621-13629. [CrossRef]

124. Mackeh, R.; Perdiz, D.; Lorin, S.; Codogno, P.; Pous, C. Autophagy and microtubules - new story, old players. J. Cell Sci. 2013, 126, 1071-1080. [CrossRef] [PubMed]

125. Matteoni, R.; Kreis, T.E. Translocation and clustering of endosomes and lysosomes depends on microtubules. J. Cell Biol. 1987, 105, 1253-1265. [CrossRef] [PubMed]

126. Korolchuk, V.I.; Rubinsztein, D.C. Regulation of autophagy by lysosomal positioning. Autophagy 2011, 7, 927-928. [CrossRef]

127. Sferra, A.; Nicita, F.; Bertini, E. Microtubule dysfunction: A common feature of neurodegenerative diseases. Int. J. Mol. Sci. 2020, 21, 7354. [CrossRef]

128. Oliveira, L.M.A.; Gasser, T.; Edwards, R.; Zweckstetter, M.; Melki, R.; Stefanis, L.; Lashuel, H.A.; Sulzer, D.; Vekrellis, K.; Halliday, G.M.; et al. Alpha-synuclein research: Defining strategic moves in the battle against Parkinson's disease. NPJ Parkinson's Dis. 2021, 7, 65. [CrossRef]

129. Lee, V.M.; Goedert, M.; Trojanowski, J.Q. Neurodegenerative tauopathies. Annu. Rev. Neurosci. 2001, 24, 1121-1159. [CrossRef]

130. Goedert, M.; Spillantini, M.G. A century of Alzheimer's disease. Science 2006, 314, 777-781. [CrossRef]

131. Pellegrini, L.; Wetzel, A.; Granno, S.; Heaton, G.; Harvey, K. Back to the tubule: Microtubule dynamics in Parkinson's disease. Cell. Mol. Life Sci. CMLS 2017, 74, 409-434. [CrossRef]

132. Cartelli, D.; Cappelletti, G. Microtubule destabilization paves the way to Parkinson's disease. Mol. Neurobiol. 2017, 54, 6762-6774. [CrossRef] [PubMed]

133. Alonso, A.C.; Grundke-Iqbal, I.; Iqbal, K. Alzheimer's disease hyperphosphorylated tau sequesters normal tau into tangles of filaments and disassembles microtubules. Nat. Med. 1996, 2, 783-787. [CrossRef] [PubMed]

134. Alonso, A.D.; Grundke-Iqbal, I.; Barra, H.S.; Iqbal, K. Abnormal phosphorylation of tau and the mechanism of Alzheimer neurofibrillary degeneration: Sequestration of microtubule-associated proteins 1 and 2 and the disassembly of microtubules by the abnormal tau. Proc. Natl. Acad. Sci. USA 1997, 94, 298-303. [CrossRef] [PubMed]

135. Brandt, R.; Bakota, L. Microtubule dynamics and the neurodegenerative triad of Alzheimer's disease: The hidden connection. J. Neurochem. 2017, 143, 409-417. [CrossRef] [PubMed]

136. Hardy, J.A.; Higgins, G.A. Alzheimer's disease: The amyloid cascade hypothesis. Science 1992, 256, 184-185. [CrossRef] [PubMed]

137. Duyckaerts, C.; Delatour, B.; Potier, M.C. Classification and basic pathology of Alzheimer disease. Acta Neuropathol. 2009, 118, 5-36. [CrossRef]

138. King, M.E.; Kan, H.M.; Baas, P.W.; Erisir, A.; Glabe, C.G.; Bloom, G.S. Tau-dependent microtubule disassembly initiated by prefibrillar beta-amyloid. J. Cell Biol. 2006, 175, 541-546. [CrossRef]

139. Giustiniani, J.; Sineus, M.; Sardin, E.; Dounane, O.; Panchal, M.; Sazdovitch, V.; Duyckaerts, C.; Chambraud, B.; Baulieu, E.E. Decrease of the immunophilin FKBP52 accumulation in human brains of Alzheimer's disease and FTDP-17. J. Alzheimer's Dis. JAD 2012, 29, 471-483. [CrossRef]

140. Herrmann, L.; Ebert, T.; Rosen, H.; Novak, B.; Philipsen, A.; Touma, C.; Schreckenbach, M.; Gassen, N.C.; Rein, T.; Schmidt, U. Analysis of the cerebellar molecular stress response led to first evidence of a role for fkbp51 in brain fkbp52 expression in mice and humans. Neurobiol. Stress 2021, 15, 100401. [CrossRef]

141. Goedert, M.; Crowther, R.A.; Spillantini, M.G. Tau mutations cause frontotemporal dementias. Neuron 1998, $21,955-958$. [CrossRef]

142. Hasegawa, M.; Smith, M.J.; Goedert, M. Tau proteins with ftdp-17 mutations have a reduced ability to promote microtubule assembly. FEBS Lett. 1998, 437, 207-210. [CrossRef]

143. Paquet, D.; Bhat, R.; Sydow, A.; Mandelkow, E.M.; Berg, S.; Hellberg, S.; Falting, J.; Distel, M.; Koster, R.W.; Schmid, B.; et al. A zebrafish model of tauopathy allows in vivo imaging of neuronal cell death and drug evaluation. J. Clin. Investig. 2009, 119, 1382-1395. [CrossRef] [PubMed]

144. Frost, B.; Jacks, R.L.; Diamond, M.I. Propagation of tau misfolding from the outside to the inside of a cell. . J. Biol. Chem. 2009, 284, 12845-12852. [CrossRef]

145. Clavaguera, F.; Bolmont, T.; Crowther, R.A.; Abramowski, D.; Frank, S.; Probst, A.; Fraser, G.; Stalder, A.K.; Beibel, M.; Staufenbiel, M.; et al. Transmission and spreading of tauopathy in transgenic mouse brain. Nat. Cell Biol. 2009, 11, 909-913. [CrossRef] 
146. Guo, J.L.; Lee, V.M. Seeding of normal tau by pathological Tau conformers drives pathogenesis of Alzheimer-like tangles. J. Biol. Chem. 2011, 286, 15317-15331. [CrossRef]

147. Criado-Marrero, M.; Gebru, N.T.; Blazier, D.M.; Gould, L.A.; Baker, J.D.; Beaulieu-Abdelahad, D.; Blair, L.J. Hsp90 co-chaperones, FKBP52 and Aha1, promote tau pathogenesis in aged wild-type mice. Acta Neuropathol. Commun. 2021, 9, 65. [CrossRef]

148. Criado-Marrero, M.; Gebru, N.T.; Gould, L.A.; Blazier, D.M.; Vidal-Aguiar, Y.; Smith, T.M.; Abdelmaboud, S.S.; Shelton, L.B.; Wang, X.; Dahrendorff, J.; et al. FKBP52 overexpression accelerates hippocampal-dependent memory impairments in a tau transgenic mouse model. NPJ Aging Mech. Dis. 2021, 7, 9. [CrossRef]

149. Sanokawa-Akakura, R.; Cao, W.; Allan, K.; Patel, K.; Ganesh, A.; Heiman, G.; Burke, R.; Kemp, F.W.; Bogden, J.D.; Camakaris, J.; et al. Control of Alzheimer's amyloid beta toxicity by the high molecular weight immunophilin FKBP52 and copper homeostasis in Drosophila. PLoS ONE 2010, 5, e8626. [CrossRef]

150. Green, K.N.; Billings, L.M.; Roozendaal, B.; McGaugh, J.L.; LaFerla, F.M. Glucocorticoids increase amyloid-beta and tau pathology in a mouse model of Alzheimer's disease. J. Neurosci. Off. J. Soc. Neurosci. 2006, 26, 9047-9056. [CrossRef]

151. Park, H.J.; Lee, S.; Jung, J.W.; Kim, B.C.; Ryu, J.H.; Kim, D.H. Glucocorticoid- and long-term stress-induced aberrant synaptic plasticity are mediated by activation of the glucocorticoid receptor. Arch. Pharmacal Res. 2015, 38, 1204-1212. [CrossRef] [PubMed]

152. Lopes, S.; Vaz-Silva, J.; Pinto, V.; Dalla, C.; Kokras, N.; Bedenk, B.; Mack, N.; Czisch, M.; Almeida, O.F.; Sousa, N.; et al. Tau protein is essential for stress-induced brain pathology. Proc. Natl. Acad. Sci. USA 2016, 113, E3755-E3763. [CrossRef] [PubMed]

153. Baschant, U.; Tuckermann, J. The role of the glucocorticoid receptor in inflammation and immunity. J. Steroid Biochem. Mol. Biol. 2010, 120, 69-75. [CrossRef] [PubMed]

154. Akiyama, H.; Barger, S.; Barnum, S.; Bradt, B.; Bauer, J.; Cole, G.M.; Cooper, N.R.; Eikelenboom, P.; Emmerling, M.; Fiebich, B.L.; et al. Inflammation and Alzheimer's disease. Neurobiol. Aging. 2000, 21, 383-421. [CrossRef]

155. Aktas, O.; Ullrich, O.; Infante-Duarte, C.; Nitsch, R.; Zipp, F. Neuronal damage in brain inflammation. Arch. Neurol. 2007, 64, 185-189. [CrossRef]

156. Kinney, J.W.; Bemiller, S.M.; Murtishaw, A.S.; Leisgang, A.M.; Salazar, A.M.; Lamb, B.T. Inflammation as a central mechanism in Alzheimer's disease. Alzheimer's Dement. 2018, 4, 575-590. [CrossRef]

157. Roos, P.M.; Vesterberg, O.; Nordberg, M. Metals in motor neuron diseases. Exp. Biol. Med. 2006, 231, 1481-1487. [CrossRef]

158. Desai, V.; Kaler, S.G. Role of copper in human neurological disorders. Am. J. Clin. Nutr. 2008, 88, 855S-858S. [CrossRef] 